\title{
Joanna SZERSZUNOWICZ
}

Uniwersytet w Białymstoku

joannaszersz@gmail.com

\section{JĘZYKOWO-KULTUROWA ANALIZA \\ SLOGANÓW REKLAMOWYCH \\ MARKI ŻUBR}

\section{WPROWADZENIE}

We współczesnym języku polskim wyraz slogan używany jest $\mathrm{w}$ dwóch znaczeniach: pierwsze $\mathrm{z}$ nich to 'oklepany zwrot; frazes, komunał'1, drugie - 'krótkie hasło propagujące lub reklamujące coś' (USJP 3: 1265). W wielu kontekstach ta jednostka leksykalna jest nośnikiem negatywnych konotacji - tę funkcję pełni na przykład w stwierdzeniu To tylko slogany. Należy jednak podkreślić, że słowo slogan nie musi mieć negatywnego nacechowania: użyte jako synonim wyrazu hasło może być neutralne i tak właśnie funkcjonuje w środowisku twórców reklamy czy językoznawców. W ujęciu terminologicznym slogan reklamowy definiowany jest w następujący sposób:

zwięzła, celna, wyrazista stylistycznie formuła słowna, skierowana do anonimowego odbiorcy, zazwyczaj anonimowa, powtarzana wielokrotnie, odwołująca się przede wszystkim do emocji, której znaczenie i forma podporządkowane są jednemu celowi, a mianowicie wzbudzeniu potrzeby nabycia towaru lub skorzystania z usługi (Kamińska-Szmaj 1996: 15)

Slogan ma charakter silnie perswazyjny, a nasycenie perswazyjnością uzyskuje się dzięki zastosowaniu rozmaitych zabiegów, między innymi za pomocą wykorzystania odwołań kulturowych. Powinien być atrakcyjny

1 Uniwersalny słownik języka polskiego podaje następujące przykłady użycia omawianego słowa w tym znaczeniu: górnolotny slogan, wypracowanie ucznia pełne sloganów, mówić slogany, operować, szermować sloganami (USJP 3: 1265). 
dla odbiorcy: oryginalny i łatwy do zapamiętania. W perspektywie językowo-kulturowej jest więc interesującym przedmiotem badań.

W Polsce, po transformacji ustrojowej w 1989 roku slogany występują głównie $\mathrm{w}$ dwóch obszarach komunikacji: w reklamie i polityce. Są one przedmiotem analiz naukowych, wśród których ważne miejsce zajmują monografie i artykuły poświęcone wyłącznie sloganom (Kochan 2007; Mosiołek-Kłosińska 1996; Lizończyk 2011). Bada się rozmaite aspekty, na przykład budowa składniowa (Zimny 1996; Kamińska-Szmaj 1996), zastosowanie frazeologizmów w reklamie (Lewicki 1995) czy językowe obrazy wybranych obiektów w tekstach reklamowych (Lewicki 1998). Oprócz wymienionych prac cennym źródłem informacji o sloganach stanowią opracowania o charakterze przekrojowym poświęcone reklamie i polityce (Skowronek 1992; Golka 1994; Kwarciak 1997), zwłaszcza te traktujące o języku polityki i reklamy, na przykład książka Jerzego Bralczyka (2004). Omawiane zjawisko opisywane jest także w pracach zakresu stylistyki: o sloganie pisze na przykład Dorota Zdunkiewicz-Jedynak (2008: 173-174) w opracowaniu Wykłady ze stylistyki².

Wiele dotychczas powstałych prac poświęconych sloganom reklamowych koncentruje się na aspektach czysto językowych, w mniejszym stopniu uwzględnia się aspekty pozajęzykowe, które również zasługują na uwagę. $Z$ tego powodu celem niniejszego artykułu jest analiza sloganów, w której uwzględnione zostaną dwa aspekty: językowy i kulturowy. Materiał badawczy stanowią hasła reklamowe marki Żubr. Przeprowadzona zostanie analiza zebranych sloganów reklamowych ${ }^{3}$, w której zostaną uwzględnione takie elementy, jak potencjał konotacyjny nazw żubr i Żubr, wykorzystanie kolorytu lokalnego, zabiegi słowotwórcze, operowanie semantyką słów występujących w sloganach oraz modyfikacje stałych połączeń wyrazowych. Omówione zostaną również aluzje do tekstów kultury oraz nawiązania stylistyczne.

2 Innymi źródłami wiedzy o sloganie są podręczniki reklamy oraz artykuły w pismach branżowych.

3 Materiał badawczy stanowi korpus obejmujący ponad sto pięćdziesiąt sloganów marki Żubr. http://www.zubr.pl/reklamy-zubra. Dostęp: 10.09.2015. 


\section{CHARAKTERYSTYKA REKLAM MARKI ŻUBR}

W 2003 roku białostocki browar Dojlidy, w którym produkowano piwo Żubr, stał się własnością Kompanii Piwowarskiej SA. Obecnie piwo to wytwarzane jest nie tylko $\mathrm{w}$ Białymstoku, ale również $\mathrm{w}$ Poznaniu i Tychach. W ramach promocji podejmowane są działania marketingowe ATL ${ }^{4}$, czyli bezpośrednio rozpoznawalne (np. w telewizji, Internecie, prasie, reklamie zewnętrznej). Jako że pierwotnie piwo wytwarzane było w pobliżu Puszczy Białowieskiej, wybór nazwy wydaje się uzasadniony. Ponadto żubr to zwierzę o dużym ekoznaczeniu w kulturze polskiej ${ }^{5}$.

Reklamy marki Żubr wykorzystują użycie apelatywnej nazwy zwierzęcia jako chrematonimu, tj. nazwy produktu (por. Breza 1998: 352) ${ }^{6}$. Jest to nazwa przeniesiona ${ }^{7}$, precyzyjniej ujmując, odapelatywna, powstała w wyniku onimizacji (Kosyl 2001: 449), a identyczność brzmienia nazwy własnej oraz rzeczownika pospolitego tworzy możliwość kreatywnych zastosowań wyrazu żubr, co ma istotne znaczenie w procesie tworzenia komunikatów o dominującej funkcji perswazyjnej.

W omawianych reklamach żubr występuje jako bohater marki (ang. brand hero $)^{8}$. Żubr postrzegany jest jako król puszczy, zwierzę majestatyczne, pełne godności i spokoju. Pokazywany jest zawsze w swoim środowisku naturalnym, czyli w puszczy. W niektórych reklamach występują również inne stworzenia mieszkające w lesie: zwierzęta i ptaki.

4 ATL - ang. above the line 'ponad linią' (above-the-line marketing). W marketing używany jest również skrótowiec BTL od angielskiego wyrażenia below the line 'poniżej linii' (below-the-line marketing), którego używa się, mówiąc o działaniach reklamowych skierowanych do konkretnego odbiorcy, ale niewystępujących w mass mediach (SM: 1).

5 W poszczególnych kulturach rozmaite zwierzęta mają duże ekoznaczenie, na przykład w kulturze australijskiej m.in. kangur i jamraj. O językowych odzwierciedleniach znaczenia kulturowego rozmaitych gatunków zob. m.in. Szerszunowicz, Vidović Bolt (2014), Wiatrowski (2015)

6 Chrematonimy to „nazwy własne niektórych materialnych wytworów ręki ludzkiej, przemysłowych lub rękodzielnicznych, jednostkowych lub seryjnych, takich, które nie są trwale związane z z określonym krajobrazem" (Kosyl 2001: 447). Zalicza się do nich nazwy: zjawisk społecznych, instytucji społecznych, przedmiotów i produktów.

7 Jak podaje Edward Breza (1998: 352), pod względem słowotwórczym chrematonimy mogą być nazwami przeniesionymi lub nieprzeniesionymi. Wśród nazw przeniesionych wyróżnia się następujące rodzaje chrematonimów: odapelatywne (np. Tarpan), odimienne (np. Danusia), odmiejscowe (Tyskie).

8 Bohaterami marek są na przykład Serce i Rozum, eksperci Tesco, Jedyny Taki. 
Warto dodać, że w kampanii reklamowej wykorzystywano również figury żubra stawiane $\mathrm{w}$ rozmaitych miejscach $\mathrm{w}$ miastach i przy drogach.

Reklamy marki Żubr wyróżniają się spójną, przemyślaną konstrukcją. Koncepcja promowania tej marki jest konsekwentnie rozwijana, a jej twórcy wykazują się dużą kreatywnością w tworzeniu coraz to nowych haseł wpisujących się $\mathrm{w}$ stworzoną przez nich formułę przypominającą film przyrodniczy.

Nie dziwi więc fakt, że marka Żubr otrzymała nagrody za swoje działania na polu reklamy. W 2006 roku otrzymała ona złotą statuetkę Effie za kampanię długofalową opracowaną dla Kompanii Piwowarskiej przez agencję PZL. Nagrody Effie przyznawane są za najskuteczniejszą kampanię marketingową: efektywność mierzona jest poprzez porównanie zakładanych przed kampanią celów z wynikami osiągniętymi po jej realizacji.

Zakładanym celem było osiągnięcie 3\% udziału marki w rynku w ciągu 12 miesięcy od wdrożenia planu marketingowego. Po 12 miesiącach, w lipcu 2004, udział w rynku wyniósł od 0,6\% do 6,5\%, a więc przekroczono zakładany poziom o 3,5\%. Celem kampanii było zbudowanie spontanicznej świadomości marki Żubr na poziomie $20 \%$, a wspomaganej - na poziomie 70\% w ciągu 12 miesięcy od wdrożenia planu. Po roku spontaniczna świadomość marki osiągnęła poziom $27 \%$, a wspomagana - aż 85\% (Zięba 2010: 6). Rok 2005 przyniósł marce srebrne Effie za efektywne wykorzystanie TV.

\section{JĘZYKOWO-KULTUROWA ANALIZA SLOGANÓW MARKI ŻUBR}

POTENCJAŁ KONOTACYJNY NAZW ŻUBR I ŻUBR

Z punktu widzenia reklamy duże znaczenie ma istnienie konotacji słów, czyli „tych elementów pragmatyki, które są odbiciem wyobrażeń kulturowych i tradycji związanych z danym wyrazem" (Apresjan 2000: 76) ${ }^{9}$. Konotacje przypisywane są referentowi ${ }^{10}$, który nabywa

\footnotetext{
9 Jurij Apresjan (2000: 76) podkreśla kulturowe uwarunkowania konotacji, które „mogą być bardzo nietypowe, "kapryśne” i różnią się znacznie dla tożsamych lub bliskich znaczeniowo wyrazów różnych języków, a nawet wyrazów jednego języka".

10 Lidia Jordanskaja i Igor Mielczuk (1988: 17) proponują następującą definicję terminu konotacja: „konotacja leksykalna jednostki leksykalnej L jest to pewna charakterystyka, którą L przypisuje swemu referentowi, i która nie wchodzi do jej definicji".
} 
„elementów znaczenia spoza ścisłej sfery semów istotnych' (Szczepankowska 2011: 82). Piotr H. Lewiński (1999: 123) zwraca uwagę na fakt, że "zwierzęta będące symbolami mają bardzo długą tradycję w kulturze jako motywy obdarzone całymi zespołami konotacji mniej lub bardziej skonwencjonalizowanych". Można przyjąc, że to właśnie konotacje wpływają zarówno na wybór nazw zwierząt na chrematonimy ${ }^{11}$, jak i na częste wykorzystywanie motywów animalistycznych $\mathrm{w}$ reklamach.

W reklamach marki Żubr istotne są konotacje obu nazw, apelatywnej i własnej. W Uniwersalnym słowniku języka polskiego apelatyw żubr definiowany jest $\mathrm{w}$ następujący sposób: 'ssak o masywnej budowie ciała, potężnym kłębie, łbie pokrytym miękkim, wełnistym włosem, tworzącym u dołu pyska rodzaj brody, żyjący obecnie w rezerwatach' (USJP 4: 1130). Inny stownik jezyka polskiego (ISJP 2: 1416) podaje ponadto informacje o rogach definiowanego zwierzęcia ('z krótkimi mocnymi rogami') oraz określenie jego barwy ('pokryte gęstą szarobrunatną sierścią'). Żubr jest zwierzęciem roślinożernym, spożywającym różne gatunki roślin. Zwierzęta o dużej masie ciała kojarzone są zazwyczaj z powolnością, ociężałością i niezdarnością ${ }^{12}$, a ponadto - jeśli nie są drapieżnikami - mogą być kojarzone z łagodnością i spokojem.

Żubr występujący w reklamach piwa ma bardziej rozbudowany potencjał konotacyjny: asocjacje uwarunkowane fizycznością żubra są podstawą do dodania dalszych konotacji. Przykładowo, duża wielkość kojarzona jest z siłą, a powolność konotuje spokój i majestatyczność, które łączą się z kolejnym elementem, mianowicie odpowiedzialnością. Jako aktywny strażnik lasu żubr troszczy się o inne zwierzęta, pomagając im w razie potrzeby (Żubr daj oparcie, Bal można oprzeć na żubrze, Kolej na żubra). Zaangażowanie wymaga od żubra inteligencji i sprytu, który wykorzystywany jest przez to zwierzę tylko $\mathrm{w}$ słusznym celu. Zwierzęta kierują się intuicją i w naturalny sposób wybierają to, co dobre (Lewiński 1999: 128). Slogany reklamowe podkreślają, że żubr jest atrakcyjny i pożądany przez innych - zarówno jako bohater reklam, jak i sam produkt (Świata poza żubrem nie widać, Kolejka do żubra).

11 Przykładowo, Kret - preparat do czyszczenia rur kanalizacyjnych, nazwy marek samochodów Jaguar i Mustang.

12 Przypisywanie zwierzętom o dużej masie ciała powolności i ociężałości znajduje odzwierciedlanie we frazeologii, na przykład w takich związkach jak: poruszać się jak niedźwiedź, wł. muoversi come un elefante [poruszać się jak słoń], camminare come un orso [chodzić jak niedźwiedź], camminare come una vacca [chodzić jak krowa] (Szerszunowicz 2011: 137). 
Wymienione cechy tworzą obraz żubra, który ma za zadanie nakłonić adresata reklamy do utożsamiania się z postawami przyjmowanymi przez żubra. Eksplicytnie wyraża to tekst reklamowy zamieszczony na stronie internetowej marki Żubr:

Od wieków na straży prastarej Puszczy Białowieskiej stoi symbol polskiej natury - Żubr. Nie można przejść obok niego obojętnie. Dostojny i majestatyczny Król Puszczy zawsze budzi respekt pośród innych gatunków. Gdy do jego królestwa wkrada się chaos, on przypomina, jak ważna jest siła spokoju. Każdy mężczyzna, niczym Król Puszczy, jest strażnikiem swojego królestwa i dba o utrzymanie jego naturalnego porządku ${ }^{13}$.

W cytowanym fragmencie eksponowane są stereotypowe cechy przypisywane mężczyźnie, takie jak opiekuńczość i opanowanie, które wykazuje bohater reklam - żubr.

Konotacje leksemu żubr stanowią więc podstawę do budowania potencjału konotacyjnego marki Żubr. Nazwa piwa Żubr przywołuje skojarzenia właśnie ze spokojem - chwilą wytchnienia po ciężkim dniu, która należy się konsumentowi tego napoju, co podkreśla ostatnie zdanie przytoczonego powyżej komunikatu reklamowego:

Dzień pełen obowiązków wieńczy zasłużonym Żubrem - piwem pełnym majestatu, zrodzonym na skraju puszczy w Browarach Dojlidy.

Konotacje te przywołują slogany Dobrze posiedzieć przy żubrze, Dobrze wpaść na żubra czy Żubr chłodzi się w cieniu. Dzięki nim nazwa Żubr wywołuje pozytywne skojarzenia: jest swoistą nagrodą za zmaganie się z trudami dnia i atrybutem spotkań z przyjaciółmi.

Warto zaznaczyć, że w reklamach, zarówno spotach, jak i billboardach, slogany zapisywane są wersalikami, więc grafia nie pozwala odróżnić rzeczownika pospolitego żubr od nazwy własnej Żubr, tym samym zacierając różnicę między apelatywem i onimem, co jest istotne dla kształtowania potencjału konotacyjnego.

Jak stwierdza Krzysztof Polak (2015), konotacje mają kluczowe znaczenie w budowaniu marki: im konotacji więcej, tym marka jest silniejsza. Umiejętne operowanie potencjałem konotacyjnym produktu za pomocą komunikatów reklamowych. Zależność marki od konotacji ilustruje wykres 1, który obrazuje, w jaki sposób produkt staje się marką.

13 Stado żubra. http://www.zubr.pl/poznaj-stado/klasyczny. Dostęp: 11.09.2015. 
WYKRES 1. Schemat potencjału konotacyjnego produktu i marki PRODUKT

MARKA

\begin{tabular}{|l|l|l|} 
poniżej 4 konotacji & 4 do 10 konotacji & powyżej 10 konotacji \\
\hline
\end{tabular}

Zero konotacji (denotacja)

Maksimum konotacji

Źródło: Polak 2015.

Marki o dobrze ustabilizowanej pozycji mają liczne konotacje: brak konotacji oznacza, że produkt to nie marka, a jedynie wytwór, który jest sprzedawany.

Podsumowując powyższe rozważania, można stwierdzić, że dzięki długoterminowym działaniom reklamowym Żubr ma rozbudowany system konotacji, co oznacza, że należy go klasyfikować jako markę. Jej konotacje są na tyle złożone, że można je analizować w kilku obszarach asocjacyjnych (Tabela 1), którymi są: społeczeństwo, natura, osobowość, intelekt i fizyczność.

TABELA 1. Znaczenie denotacyjne i konotacyjne marki Żubr

\begin{tabular}{|l|l|}
\hline \multicolumn{2}{|c|}{ MARKA ŻUBR } \\
\hline \multicolumn{2}{|c|}{ Znaczenie denotacyjne } \\
\hline \multicolumn{2}{|c|}{ mączmiennego produkowanego przez Kompanię Piwowarską }
\end{tabular}

Źródło: Opracowanie własne na podstawie Polak 2015.

Powyższa tabela pokazuje, jak mocno został rozbudowany system konotacji marki Żubr dzięki rozwijaniu cech zwierzęcia w poszczególnych 
spotach, co zostało odzwierciedlenie w sloganach. Zakładając, że będą powstawać kolejne reklamy, można przewidywać, że konotacje w poszczególnych obszarach będą coraz liczniejsze.

\section{NATURA}

Natura przeciwstawiana jest wytworom działalności człowieka, a to, co naturalne, góruje nad tym, co stworzyli ludzie. Jak podaje Lewiński (1999: 145), natura konotuje „pierwotność, czystość, siłę, brak skażenia cywilizacyjnego, zdrowie, eden, szczęście, potęgę, życie, piękno, zmysłowość". Świat reklamy marki Żubr to właśnie natura: puszcza, polana, leśna droga i inne miejsca, w których żyją zwierzęta. W spotach reklamowych pojawiają się tylko one, natomiast nie widzimy ludzi. Ponadto słyszymy odgłosy przyrody, na przykład ćwierkanie ptaków ${ }^{14}$.

Natura jawi się człowiekowi korzystającemu z dóbr cywilizacji jako obszar niezwykle atrakcyjny, gdzie raczej bywa niż jest, a jego przebywanie tam wiąże się w wypoczynkiem. Dzięki niecodzienności pobyt na łonie natury dostarcza ludziom wrażeń estetycznych i poznawczych. Habitat żubra to puszcza, więc wykorzystanie motywu natury - pozytywnie odbieranego przez odbiorców - w reklamie jest uzasadnione tematycznie. Należy podkreślić, że ma ono moc argumentacji topicznej, ponieważ stanowi odwołanie do istniejących przekonan - w tym przypadku o wyższości natury nad cywilizacją i jej problemami - i wzmocnienie ich w tekście reklamowym (por. Lewiński 1999: 143).

Slogany zawierają bezpośrednie nawiązania do świata przyrody, które przejawiają się na poziomie leksykalnym. W większości z nich występuje nazwa $\dot{z} u b r$ oraz inne wyrazy z makropola semantycznego NATURA. Jedno $z$ haseł reklamowych zawiera samą nazwę pola: w sloganie $Z$ natury przyciaga wyraz ten jest składnikiem stałego połączenia wyrazowego, które poprzez osadzenie w kontekście przyrody wywołuje szereg skojarzeń.

14 Przestrzeń w reklamie ma swoją własną organizację: jest skinetyzowana i zhierarchizowana sposób znaczący (Szczęsna 2001: 161), co doskonale widać w reklamie marki Żubr. Zauważalna jest również symplifikacja natury przedstawionej w spotach. 


\section{KOLORYT LOKALNY}

Jak już wspomniano, pierwotnie piwo Żubr było flagowym produktem białostockiego browaru Dojlidy, a więc było wytwarzane w województwie podlaskim. Na jego terenie znajduje się Puszcza Białowieska, obszar nieskażonej przyrody z dziewiczymi starodrzewami. Żubr jest zwierzęciem kojarzonym $\mathrm{z}$ tym regionem: widnieje na pocztówkach i folderach reklamowych, był motywem wykorzystanym w logo województwa, produkowane są drewniane figurki żubra, które sprzedawane są jako pamiątki. Występuje również w herbach (np. Białowieży, powiatu Hajnówka, Narewki, Tykocina, Zambrowa, Sokółki). Żubr ma swoje pomniki: pierwszy znajduje się w Białowieży (replika pomnika z 1862 r., upamiętniającego polowanie Aleksandra II), drugi zaś - w Zambrowie. Pojawia się również w innych kontekstach: przykładowo, Żubr budzi Podlasie to tytuł konkursu na ciekawe inicjatywy prospołeczne $\mathrm{w}$ wymienionym $\mathrm{w}$ haśle regionie.

Pojawienie się żubra w reklamie można traktować jako element kolorytu lokalnego. Z punktu widzenia reklamy ma to duże znaczenie: patriotyzm lokalny odgrywa dużą rolę w budowaniu strategii marki (por. Siemieniako 2014). Wybory współczesnego konsumenta uwarunkowane są coraz większym stopniu świadomością i postawami konsumentów w stosunku do lokalnych czy regionalnych marek, co pokazują badania nad etnocentryzmem konsumentów różnych produktów (Falkowski, Rożnowski, Witkowski 1996), w tym kupujących piwo (Siemieniako, Kubacki, Krot, Glińska 2011).

Te czynniki również miały wpływ na sposób budowania pozycji konkurencyjnej marki Żubr na rynku. Nazwa piwa doskonale komponuje się z wizerunkami zwierzęcia na opakowaniach oraz z materiałach reklamowych, w których tłem jest puszcza, a więc również element charakterystyczny dla Podlasia.

Na uwagę zasługują również slogany, które tworzone są według schematów, w których komponentem podlegającym substytucji jest nazwa własna miejscowa. Model Żubr wychyla się w + nazwa miejscowa wykorzystano do utworzenia sloganów z różnymi toponimami, na przykład Żubr wychyla się w Białymstoku.

Inny model używany w reklamach tej marki to oparty na dwuznaczności komponentów schemat Żubr $w$ + nazwa miejscowa + się należy. Realizuje go między innymi slogan Żubr w Grabówce się należy. 
ILUSTRACJA 1. Reklama marki Żubr przy placu Uniwersyteckim w Białymstoku

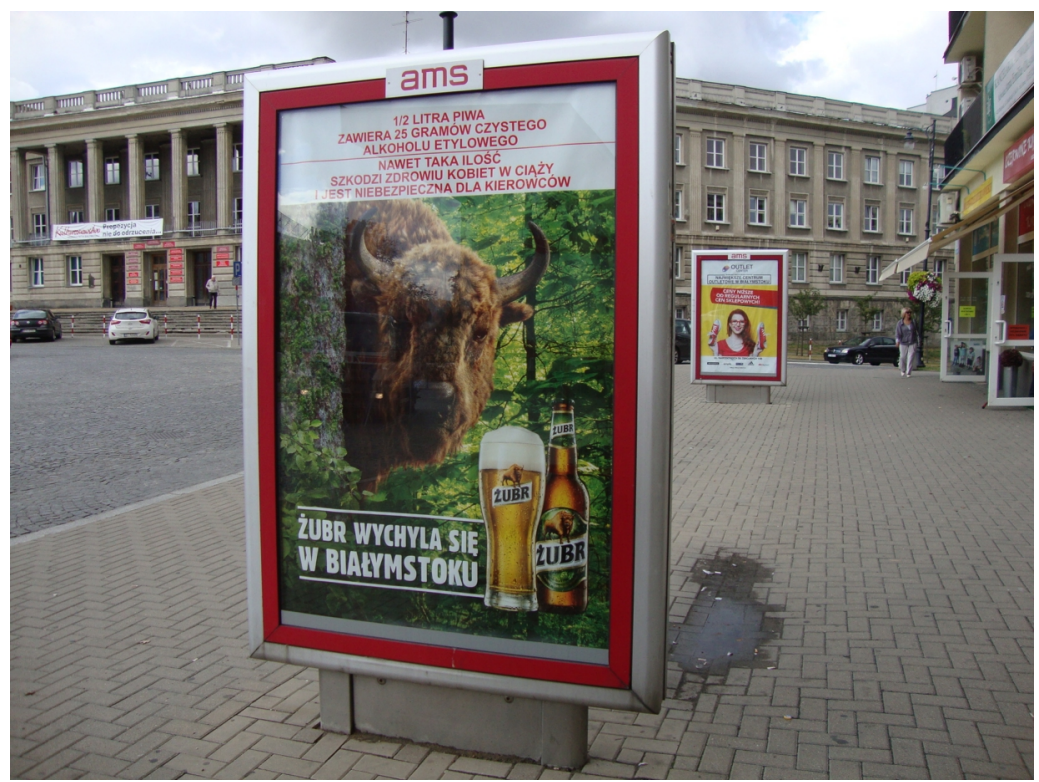

Fot. Autor

ILUSTRACJA 2. Reklama marki Żubr przy Szosie Baranowickiej w Grabówce

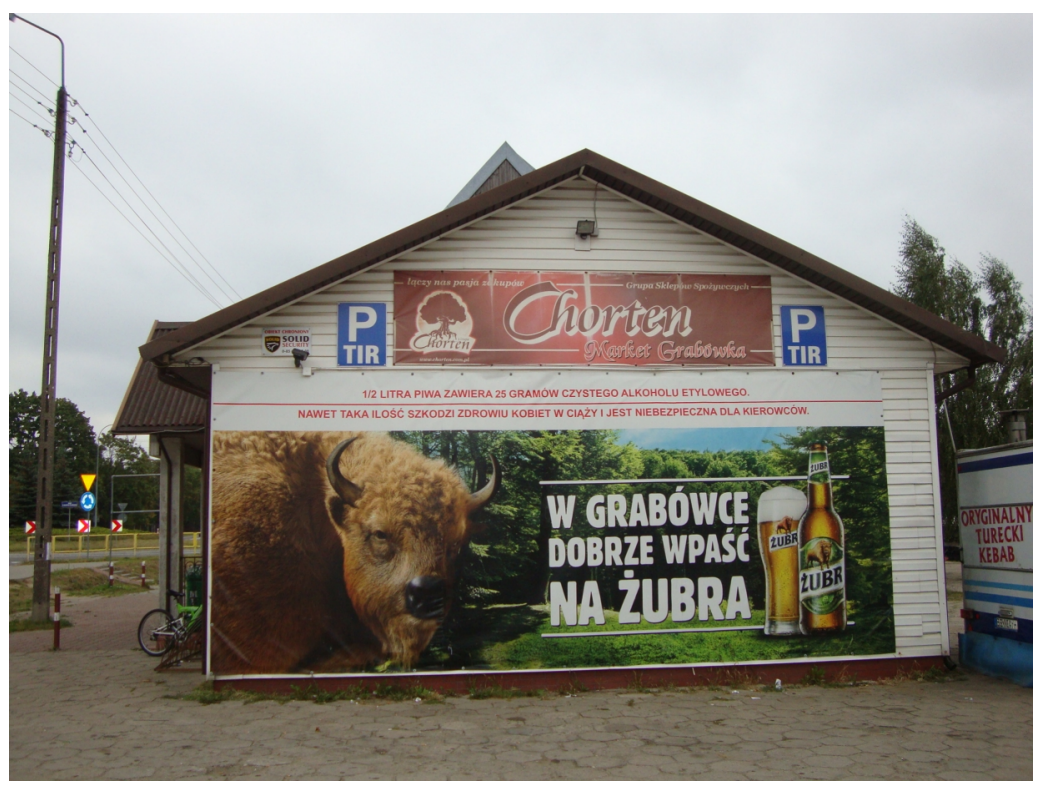

Fot. Autor 
Toponim ulega substytucji zależnie od miejsca, w którym znajdzie się reklama zewnętrzna. Takie operowanie onimem pozwala na wprowadzenie do reklamy kolorytu lokalnego, a w konsekwencji stanowi odwołanie do poczucia patriotyzmu lokalnego konsumentów. Zabieg ten ma również na celu wywołanie sympatii do produktu, który staje się im bliższy dzięki danej nazwie miejscowej.

\section{DYSONANS KULTUROWY}

Wykorzystanie dysonansu kulturowego jest jedną ze strategii działań marketingowych przedstawianych przez Douglasa Holta (2004). Polega ona na operowaniu dysonansem istniejącym między dominującymi $\mathrm{w}$ danej kulturze ideologiami a codziennymi praktykami.

Jako przykład wykorzystania omawianej strategii na gruncie polskim Krzysztof Polak (2015) podaje strategię marki Żubr we wczesnym okresie jej istnienia. Silnie zaznaczały się wówczas tendencje do przejawiania dużej życiowej aktywności, odnoszenia sukcesów w różnych sferach, włączania się w rywalizację określaną mianem wyścigu szczurów.

Ostra rywalizacja i szybkie tempo zadecydowały o tym, że część społeczeństwa nie była w stanie sprostać tym wyzwaniom, które im postawiono. W konsekwencji nienadążania za zmianami i niespełnienia oczekiwań społecznych grupa ta poczuła się odrzucona i znalazła się na marginesie kultury (Polak 2015).

Zostało to wykorzystane w strategii marki Żubr, która zaczęła promować ideologię, która nie narzucała wymagań i nie wiązała się z szybkim i intensywnym stylem życia. Ideologię tej marki można określić jako przeciwną w stosunku do dominującej: jej założenie to „nic nie musisz" w opozycji do "musisz odnosić sukcesy”.

Dysonans ten obecny jest również w późniejszym okresie: teksty reklamowe wpisują się w konwencję spokojnego życia, relaksu, zwłaszcza na łonie natury. Slogany takie jak Dobrze posiedzieć przy żubrze, Rano kawka wieczorem żubr, Wieczorem podchodzi bardziej, Zasmakuj w sile spokoju czy Wieczorem idzie żubr za żubrem promują styl życia, w którym jest czas na spotkania towarzyskie i wypoczynek.

\section{POWIĄZANIE Z RYTUAŁEM}

Rytuał ma duże znaczenie w budowaniu marki (Holt 2004: 60). W reklamach marki Żubr widoczne są powiązania z rytuałem: picie piwa 
ma miejsce podczas spotkań towarzyskich: wieczorów spędzanych w barach czy też przy grillu, a więc to czynność o charakterze zrytualizowanym. Wymienione rodzaje aktywności społecznej mają duże znaczenie w perspektywie kulturowej. Pisząc o grillowaniu, Krzysztof P. Skowroński (2007: 373) zwraca uwagę na ,jego charakter kulinarno-rekreacyjno-towarzyski, pozwalający na spełnienie kilku ważnych funkcji mniej więcej w tym samym stopniu ". Stwierdzenie to można odnieść również do innych form spotkań.

$\mathrm{Z}$ amerykanizacją zachowań, $\mathrm{w}$ tym również na gruncie towarzyskim, wiąże się wzrost znaczenia wspólnego spędzania czasu poza domem po południu i wieczorem, w barach, pubach, restauracjach itd. (Skowroński 2007: 374). Spotkania te najczęściej odbywają się w większym gronie i umacniają więzy towarzysko-zawodowe. Picie piwa staje się rytuałem związanym z nimi - po dniu zmagań z codziennymi obowiązkami pojawienie się napoju marki Żubr symbolizuje rozpoczęcie relaksu, a więc wprowadza dobrą atmosferę. Wspólne spożywanie tego produktu ma ponadto wymiar integrujący daną grupę. Można tu również doszukiwać się nawiązań do staropolskich tradycji biesiad i polowań, których obraz przywołuje pokazywana w spotach puszcza.

Analiza komunikatów reklamowych marki Żubr pozwala wskazać stałe elementy budujące lub wspomagające rytualizację. Można je analizować na dwóch płaszczyznach: na poziomie sloganów oraz na poziomie koncepcji reklamy. Hasła reklamowe eksponują wieczór jako porę spożywania piwa Żubr (Wieczorem podchodzi bardziej). Niektóre z nich sygnalizują, że piwno powinno być schłodzone (Żubr chłodzi się w cieniu), a inne hasła tej marki podkreślają, że nie należy ograniczać się do wypicia jednego kufla piwa: Co dwa żubry to nie jeden, Co dwa wychylenia to nie jedno. Slogan Żubr podchodzi do grilla przekazuje, że picie piwa jest charakterystyczne dla spotkań przy grillu.

W pewnym sensie można przyjąć, że sama reklama marki Żubr uległa rytualizacji na poziomie struktury. Konsekwencja, z jaką prowadzone są kolejne kampanie, wyznaczyła linię jej rozwoju. Duża powtarzalność elementów reklamy (bohater, miejsce, dowcipny slogan) doprowadziła do stworzenia konwencji form promocji tej marki.

WYKORZYSTANIE LEKSYKI

W sloganach marki Żubr dominują wyrazy z makropola semantycznego NATURA, na przykład: puszcza, trawa, jęczmień, dzięcioł, kawka. Warto 
odnotować, że nawet niektóre stałe połączenia wyrazowe wybrane do modyfikacji mają w swoim składzie wyrazy z tego właśnie makropola. Mogą to być słowa występujące w postaci kanonicznej danego związku (np. las: Im dalej w las, tym więcej...) lub elementy ulegające substytucji (Lepszy żubr w garści niż dzięcioł na sęku). Konsekwentne operowanie leksyką z pola NATURA współgra z obrazami wykorzystywanymi w reklamach żubra, co zapewnia spójność, a w rezultacie zwiększa perswazyjność komunikatów reklamowych.

Charakterystyczne dla reklam wyrazy wartościujące nie są zbyt często wykorzystywane w reklamach marki Żubr. Przysłówek dobrze wystąpił w sloganie Dobrze wpaść na żubra, najlepszy - w haśle Najlepszy efekt daje wychylenie żubra. Użycie w sloganach wyrazów nacechowanych aksjologicznie może wynikać $z$ ich obecności w stałych połączeniach wyrazowych ulegających przekształceniom (np. lepszy: Lepszy żubr w garści niż dzięcioł na sęku; dobrze, najlepiej: Wszędzie dobrze, ale z żubrem najlepiej).

W analizowanym materiale liczne są kreatywne użycia jednostek leksykalnych. Przykład wykorzystania neologizmu występuje w sloganie $\dot{Z} u$ brujemy. Czasownik *zubrować jest derywatem czasownikowym utworzonym od rzeczownika żubr. Posłużenie się formą pierwszej osoby liczby mnogiej wprowadza inkluzję: „my” oznacza zbiorowość konsumentów piwa. Użycie tej formy pełni funkcję integrującą, a jej oryginalne brzmienie nadaje czynności wyjątkowego charakteru.

Innym przykładem twórczego posługiwania się leksyką jest slogan Żubr z Białego Stoku, w którym nazwa Białystok zyskała nową grafię. Zapisanie nazwy miasta jako dwóch wyrazów stwarza dwie możliwości odczytania: osoby, które wiedzą, że piwo Żubr produkowane jest w browarze w Białymstoku, natychmiast odczytają aluzję.

Najliczniej reprezentowane jest wykorzystanie polisemii: wiele sloganów powstało dzięki wprowadzeniu do nich dwuznaczności. Zabieg ten możliwy jest dzięki odpowiedniemu posłużeniu się wyrazem lub wyrazami o dwóch znaczeniach, tj. umieszczeniu takiego słowa lub takich słów w kontekście umożliwiającym różne sposoby odczytania.

Przykładowo, slogan Rano kawka wieczorem żubr zawiera dwie nazwy animalistyczne: nazwę ptaka kawka oraz nazwę ssaka - żubr. Słowo kawka na dwa znaczenia, mianowicie jest ono nazwą ptaka oraz określeniem małej filiżanki kawy. Z kolei wyraz żubr to nazwa zwierzęcia oraz potoczne określenie piwa marki Żubr. 
Możliwość dwojakiego odczytania uwarunkowana jest często pokazaniem w reklamie obrazu, który skłania do dosłownego odczytania danego hasła reklamowego. Przykładowo, slogan Żubr powstaje z jęczmienia użyty jest w spocie pokazującym, jak żubr podnosi się wśród łanów zbóż. Znaczenie czasownika powstaje odczytać można jako 'podnosi się' w odniesieniu do zwierzęcia w spocie oraz 'jest wytwarzane' - w odniesieniu do produktu. Inne hasła reklamowe oparte na dwuznaczności to między innymi: Tuż za rogiem, Żubr chłodzi się w cieniu, Wieczorem żubr idzie za żubrem, Żubra uchwycić to radość, Żubr na dworze, Najlepszy efekt daje wychylenie żubra, Żubr szybko schodzi.

\section{MODYFIKACJE STAŁYCH POŁĄCZEŃ WYRAZOWYCH}

W zasobach języków naturalnych występuje wiele wielowyrazowych konstrukcji o charakterze odtwarzalnym, czyli reproduktów (Chlebda 2005: 160-163) ${ }^{15}$. Zalicza się do nich rozmaite rodzaje ustabilizowanych kombinacji wyrazowych, na przykład frazeologizmy, przysłowia i skrzydlate słowa. W reklamie mogą być one wykorzystywane zarówno w postaci kanonicznej, jak i w formie zmodyfikowanej. Drugi z wymienionych sposobów użycia tych jednostek - z racji atrakcyjności dla odbiorcy - jest nader często stosowany w komunikatach reklamowych.

W badanym materiale licznie reprezentowane są jednostki przekształcone, czyli kreatywne adaptacje stałych połączeń wyrazowych. Najczęściej stosowanym zabiegiem jest substytucja, która polega na zamienieniu jednego komponentu związku kanonicznego innym. Przykładowo, powiedzenie Muzyka łagodzi obyczaj po substytucji ma postać Żubr łagodzi obyczaje: zamiast słowa muzyka użyta została nazwa Żubr. W wielu przypadkach to właśnie ona pojawia się w transformacjach, na przykład: Nie chwal dnia zachodem słońca $\rightarrow$ Nie chwal dnia przed żubrem, Co dwie glowy to nie jedna $\rightarrow$ Co dwa żubry to nie jeden, Wszystkie drogi prowadza do Rzymu $\rightarrow$ Wszystkie drogi prowadza do żubra, Wszędzie dobrze, ale w domu najlepiej $\rightarrow$ Wszędzie dobrze ale... z żubrem najlepiej, Cudze chwalicie, swego nie znacie $\rightarrow$ Cudze chwalicie, żubra nie znacie. W jednym ze sloganów doszło do substytucji większej liczby elementów: Lepszy wróbel w garści niż gołąb na dachu $\rightarrow$ Lepszy żubr w garści niż dzięcioł na sęku.

15 Jak podaje Wojciech Chlebda (2007: 18), „kryterium odtwarzalności w danej sytuacji pozwala ustalać wspólny mianownik dla tworów o różnym statusie formalnym i znaczeniowym". 
W niektórych modyfikacjach nazwa Żubr nie występuje eksplicytnie jako werbalny komponent przekształconego związku. Przykładem takiej adaptacji jest slogan Co dwa wychylenia to nie jedno. W haśle reklamowym Im dalej $w$ las, tym więcej..., które powstało w wyniku modyfikacji przysłowia Im dalej w las, tym więcej drzew. Po wielokropku pokazane są butelki, na których widnieje nazwa Żubr. W analizowanym przykładzie mamy więc do czynienia z kreatywnym łączeniem elementów różnych kodów.

Wśród analizowanych sloganów mniej liczne są transformacje związków frazeologicznych. Występują substytucje jednego komponentu, na przykład bez kija nie podchodź $\rightarrow$ Bez żubra nie podchodź. W przypadku frazeologizmu Świata poza żubrem nie widać zastosowano permutację komponentów związku nie widzieć poza kimś, czymś świata [bożego] (WSFJP: 789). Ponadto czasownik widzieć, który zgodnie z paradygmatem powinien wystąpić w formie osobowej, został zastąpiony bezokolicznikiem widać.

Inny slogan, Żubr w trawie puszczy, również powstał w wyniku złożonej transformacji: jednostka frazeologiczna wiedzieć co w trawi pisz$c z y^{16}$, realizującej schemat kto + wie co w trawie piszczy (SFWP: 847-848). Można tę modyfikację traktować jako redukcję połączoną z substytucją, w której wykorzystano paronimiczną relację zachodzącą między wyrazami puszczy i piszczy. W jednym ze sloganów wystąpiła amplifikacja: do tytułu kolędy, a zarazem jej początkowego wersu została dodana nazwa Żubr. W rezultacie tego zabiegu utworzony został slogan Żubr wśród nocnej ciszy ${ }^{17}$.

\section{STYLIZACJA, ALUZYJNOŚĆ, INTERTEKSTUALNOŚĆ}

W sloganach reklamowych znajdujemy wiele wykładników intertekstualności, między innymi nawiązań kulturowych, takich jak we wspomnianym sloganie Żubr wśród nocnej ciszy, i stylistycznych. Przykładowo, hasło przewodnie i nazwa kampanii reklamowej z 2003 roku Żubr występuje w puszczy nawiązuje do stylu naukowego, dla którego charakte-

\footnotetext{
16 Wielki słownik frazeologiczny języka polskiego (WSFJP: 818) podaje zapis wiedzieć, co w trawie piszczy.

17 Modyfikowane są te ideonimy, które są dobrze znane przeciętnemu użytkownikowi języka, na przykład filmów (Podróż za jeden leasing, reklama Polskiego Towarzystwa Leasingowego). Podobnie jest w przypadku parafraz fragmentów tekstów (Zmywać to nie znaczy zawsze to samo, slogan reklamujący zlewozmywaki Franke).
} 
rystyczne są formy czasu teraźniejszego i użycia rzeczownika w liczbie pojedynczej dla oznaczenia wszystkich okazów danego gatunku. Slogan Żubr występuje w puszczy przywołuje skojarzenia ze stylem tekstów z podręczników do przyrody, w których "można znaleźć formuły typu $W$ Polsce żubr występuje w Puszczy Białowieskiej (...)" (SSR: 218) ${ }^{18}$. Odwołania do tej konwencji znajdujemy również w haśle Żubr powstaje z jęczmienia.

Oprócz nawiązań do innych tekstów jak, takich dzieła literackie czy filmy ${ }^{19}$, same slogany mogą budować sieć powiązań. Dzieje się tak wtedy, kiedy zawierają one fragmenty innych sloganów, wykorzystują tę samą strukturę ${ }^{20}$ lub oparte są na jednym koncepcie. Tak jest w przypadku wykorzystania semantyki wyrazu bal w sloganach Bal można oprzeć na żubrze, Bal od żubra do żubra, Żubr po balu i Żubr na balu. Hasła te oparte są na dwuznaczności, która jest rezultatem użycia jednego słowa, a więc są one powiązane tym konceptem.

\section{WNIOSKI}

Analiza sloganów reklamujących markę Żubr wykazała, że w ich tworzeniu istotną rolę odgrywają różnorodne czynniki językowo-kulturowe. Hasła odwołują się do kolorytu lokalnego Podlasia, eksponując miejsce występowania żubra oraz lokalizację zakładu produkującego piwo tej marki. W sloganach tych znajdujemy odwołania do zachowań rytualnych, zwłaszcza tych związanych z biesiadowaniem. Marka ta wykorzystała w swojej kompanii zjawisko dysonansu kulturowego, co miało również wpływ na postać sloganów. Toposem, który pojawia się w reklamach, jest natura.

Przyroda stanowi jeden z obszarów asocjacji, które wywołują slogany u odbiorcy komunikatów reklamowych Żubra. Potencjał konotacyjny sloganów jest duży i można wskazać również inne obszary, na przykład społeczeństwo, osobowość i fizyczność. Konotacje odgrywają bardzo duże

$18 \mathrm{~W}$ spocie pojawiają się cztery żubry nucące melodię, co nasuwa inną interpretację czasownika występuje, mianowicie 'jest wykonawcą utworu muzycznego'.

19 Warto dodać, że w reklamie Żubr występuje w puszczy wykorzystano muzyczne odwołanie kulturowe, towarzyszy mu bowiem melodia piosenki Nim wstanie dzien, skomponowanej przez Krzysztofa Komedę.

20 Na przykład slogan Twój kot kupowałby Whiskas został sparafrazowany w hasłach Twoja mysz czytałaby DECforum czy Twój wielbłąd kupowałby Lucky Strike (Kochan 2007: 141). 
znaczenie w budowaniu marki i umacnianiu jej pozycji na rynku. W przypadku marki Żubr nowe slogany rozbudowują jej system konotacyjny, wzbogacając go o nowe elementy.

Wykorzystanie tej techniki umożliwia konsekwentne rozwijanie przyjętej koncepcji reklamy tej marki, co zapewnia jej rozpoznawalność wśród odbiorców. Stylizacja spotów, w których pojawiają się slogany, na film przyrodniczy pozwala na stworzenie ciągu opowiadań. Hasła te wpisują się doskonale w konwencję przyjętą przez twórców tych reklam: przekazu werbalny współgra z obrazem i udźwiękowieniem.

W sloganach znajdujemy rozmaite kreatywne użycia języka. Do najczęściej wykorzystywanych zabiegów należą modyfikacje stałych połączeń wyrazowych oraz wykorzystywanie dwuznaczności wyrazów występujących w hasłach. Slogany te mogą być dwojako interpretowane, co sprawia, że pełnią funkcję ludyczną i są atrakcyjne dla odbiorcy.

Podsumowując, można stwierdzić, że slogany reklamowe marki Żubr budują jej pozytywny wizerunek za pomocą umiejętnego połączenia rozmaitych środków, zarówno poprzez kreatywne wykorzystanie zasobów językowych, jak i dzięki odpowiedniemu zastosowaniu odwołań pozajęzykowych w odpowiedniej oprawie wizualno-dźwiękowej.

\section{BIBLIOGRAFIA}

\section{SŁOWNIKI}

ISJP - Inny słownik języka polskiego, 2000, red. M. Bańko, t. 1-2, Warszawa.

SFWP - Bąba S., Liberek J., 2002, Słownik frazeologiczny wspótczesnej polszczyzny, Warszawa.

SM - Ivanovic A., Collin P.H., Słupski J., 2000, Słownik marketingu, Warszawa.

SSR - Spychalska M., Hołota M., 2009, Słownik sloganów reklamowych, Warszawa. USJP - Uniwersalny słownik jezzyka polskiego, 2003, red. S. Dubisz, t. 1-4, Warszawa. WSFJP - Mülder-Nieckowski P., 2003, Wielki słownik frazeologiczny języka polskiego, Warszawa.

\section{LITERATURA}

Apresjan Ju., 2000, Semantyka leksykalna. Synonimiczne środki języka, przekł. Z. Kozłowska, A. Markowski, Wrocław-Warszawa-Kraków.

Breza E., 1998, Nazwy obiektów i instytucji zwiazanych z nowoczesna cywilizacja (chrematonimy), [w:] Polskie nazwy własne. Encyklopedia, red. E. Rzetelska-Feleszko, Kraków-Warszawa, s. 343-361. 
Bralczyk J., 2004, Język na sprzedaż, czyli o tym, jak język służy reklamie i jak reklama używa języka, Gdańsk.

Chlebda W., 2005, Szkice o skrzydlatych słowach. Interpretacje lingwistyczne, Opole.

Chlebda W., 2007, Mały prywatny katalog pilnych zadan frazeologicznych, „Problemy Frazeologii Europejskiej", t. VII, 15-31.

Falkowski A., Rożnowski B., Witkowski T., 1996, Etnocentryzm konsumentów nowe wyzwania dla marketingu, „Marketing i Reklama”, nr 4, s. 6-11.

Golka M., 1994, Świat reklamy, Warszawa.

Holt D., 2004, How Brands Become Icons: The Principles of Cultural Branding, Boston.

Janiszewska K. i in., 2009, Wiedza o reklamie. Od pomysłu do efektu, Warszawa-Bielsko-Biała.

Jordanskaja L., Mielczuk I., 1988, Konotacja w semantyce lingwistycznej i leksykografii, [w:] Konotacja, red. J. Bartmiński, Lublin, s. 9-34.

Kamińska-Szmaj I., 1996, Slogan reklamowy - budowa składniowa, „Poradnik Językowy", z. 4, s. 13-22.

Kochan M., 2007, Slogany w reklamie i polityce, Warszawa.

Kosyl Cz., 2001, Chrematonimy, [w:] Wspótczesny język polski, red. J. Bartmiński, Lublin, s. 447-452.

Kwarciak B., 1997, Co trzeba wiedzieć o reklamie, Kraków.

Lewicki A. M., 1995, Frazeologizmy w sloganach reklamowych, [w:] Kreowanie świata $w$ tekstach, red. A. M. Lewicki, R. Tokarski, Lublin, s. 215-228.

Lewicki A. M., 1998, Jezzyk a Kultura 12: Stereotyp jako przedmiot lingwistyki. Teoria, metodologia, analizy empiryczne, red. J. Anusiewicz, J. Bartmiński, Wrocław, s. 206-223.

Lewiński P. H., 1999, Retoryka reklamy, Wrocław.

Lizończyk I., 2011, „Today. Tomorrow. Toyota.": językowa analiza sloganów reklamowych, Kultura i Polityka: Zeszyty Naukowe Wyższej Szkoły Europejskiej im. Ks. Józefa Tischnera w Krakowie, nr 10, s. 77-87.

Mosiołek-Kłosińska K., 1996, Slogany wyborcze jako wypowiedzi podsumowujace treści głoszone przez polityków (na materiale tekstów z kampanii prezydenckiej 1995 r.), „Przegląd Humanistyczny", nr 4, s. 105-118.

Polak K., 2015, Kiedy produkt staje się marką, „Marketing w Praktyce, 2. http:// semiotyka.com/blog/portfolio_page/branding/. Dostęp: 25.08.2015.

Szczęsna J., 2001, Poetyka reklamy, Warszawa.

Siemieniako D., 2014, Patriotyzm lokalny a lojalność konsumentów piwa w budowie strategii marki, „Marketing i Rynek”, nr 8, s. 1242-1248.

Siemieniako D., Kubacki K., Krot K., Glińska E., 2011, The ethnocentric tendencies among beer drinkers as a specific relation with local brands in Poland, British Food Journal, No 113(3), s. 409-411.

Skowronek K., 1992, Reklama. Studium pragmalingwistyczne, Kraków. 
Skowroński K. P., 2007, Amerykanizacja polskiej kultury kulinarnej. Przegląd zagadnień, [w:] Pokarmy i jedzenie w kulturze. Tabu, dieta, symbol, red. K. Łeńska-Bąk, Opole, s. 361-381.

Szczepankowska I., 2011, Semantyka i pragmatyka językowa, Białystok.

Szczęsna E., 2001, Poetyka reklamy, Warszawa.

Szerszunowicz J., 2011, Obraz człowieka w polskich, angielskich i włoskich leksykalnych i frazeologicznych jednostkach faunicznych, Białystok.

Szerszunowicz J., Vidović Bolt J., 2014, Kulturowe znaczenie komponentu frazeologizmu a jego międzyjęzykowa ekwiwalencja, „Białostockie Archiwum Językowe”, nr 14, s. $195-216$.

Wiatrowski P., 2015, The Cultural Relevance of Indonesian Phraseological Units as Contrasted with Polish, „Humaniora” 27(1), s. 14-26.

Zdunkiewicz-Jedynak D., 2008, Wykłady ze stylistyki, Warszawa.

Zięba K., 2010, Skuteczność działań marketingowych, Zeszyty Naukowe Polityki Europejskie, Finanse i Marketing, nr 3(52), s. 278-287.

Zimny R. 1996, Niektóre cechy składni wspótczesnego sloganu reklamowego, „Język Polski", t. LXXVI, z. 2-3, s. 147-154.

STRONA INTERNETOWA

http://www.zubr.pl. Dostęp: 10.09.2015.

\section{A LINGUO-CULTURAL ANALYSIS OF ADVERTSING SLOGANS OF THE ŻUBR BRAND}

\section{Summary}

The aim of the paper is to analyse slogans of the Żubr brand in a linguocultural perspective. The focal issues of the study are the following aspects: creating the connotative potential of the names $\dot{z} u b r$ ('bison', the name of the animal) and $\dot{Z} u b r$ (the beer brand name), using nature as a topos as well as referring to the local color of the region of Podlasie. The cultural dissonance implementation and the ritualization references are also discussed. The linguistic aspects of the analysis comprise the use of lexis and fixed expressions, both in their standard and modified forms. Moreover, the intertextuality of the slogans is analyzed. The research study shows that thanks to the development of the advertising conception, the slogans of this brand play an important role in the creation of the brand on the market and the enhancement of its position.

Key words: slogan, beer advertising, linguo-cultural analysis, Żubr brand 